\title{
W Edwards Deming: father of quality management, patient and composer
}

\author{
M Best, D Neuhauser
}

Qual Saf Health Care 2005;14:310-312. doi: 10.1136/qshc.2005.015289

"The right quality and uniformity are foundations of commerce, prosperity and peace." W E Deming (19001993)

$\mathrm{V}$ ariation causes waste. How could any one take these apparently simple ideas and turn them into the path to peace and prosperity? W Edwards Deming did. It took a long life and he changed the world.

\section{WASTE NOT}

William Edwards Deming, the first child of William Albert Deming and Pluma Irene Edwards, was born on 14 October 1900 in Sioux City, Iowa. His father worked mainly in freelance legal work and his mother gave music lessons on their grand Kimball piano. As a child, Deming grew up in meagre conditions. He and his family lived for years in a tarpaper shack. As a boy he worked at a hotel for $\$ 1.25$ per week and he lit the town's five gasoline street lamps every evening for $\$ 10.00$ per month. ${ }^{1}$ These early years probably influenced formation of his frugal behavior, his attitude toward productivity and quality improvement, and his campaign against waste and processes that do not add value.

\section{STATISTICS AND PSYCHOLOGY}

In 1917 Deming started attending the University of Wyoming while working at several odd jobs to support himself. He played the drums and timpani in the university band, but switched to the piccolo in his second year as it was easier to transport to off campus events. He received his bachelor's degree in electrical engineering in 1921, and in 1922 he married and took a job teaching physics at the Colorado School of Mines. He also attended classes at the University of Colorado and earned a master's degree in mathematics and physics in 1925. Deming was encouraged to attend Yale to get a doctorate, and in 1928 he was awarded a doctorate in mathematical physics. While studying for his PhD, Deming taught at Yale as an instructor which paid $\$ 1000$ per year.

In 1925 and 1926 Deming spent the summer months working at the Western Electric Hawthorne Plant. This plant was made famous by the experiments of Elton Mayo on worker productivity which resulted in the appreciation of the so-called "Hawthorne effect". While at the Hawthorne plant in Chicago, Deming met Walter A Shewhart. Dr Shewhart became Deming's mentor and taught him how to apply statistics to measure and control process variation. The understanding of variation became one of the key elements of the Deming philosophy. If you are making cars, your customers want doors that fit the body of the car-not too big that they will not close and not so small that they let in the rain. Patients treated off best practice guidelines receive unacceptable variation in care. Customers and patients should buy cars and seek care elsewhere. Such variation causes waste and harm. Without customers there will be no jobs, no prosperity, and, ultimately, no peace.

After completing his studies at Yale, Deming was presented with several job offers. He accepted a position studying the effects of nitrogen on crops with the United States Department of Agriculture (USDA) in the Fixed Nitrogen Research Laboratory in Washington DC. During his tenure at the USDA Deming published 24 papers, most of which discussed the physical properties of gases. In 1939 he accepted a job with the US Census Bureau where he published several papers on sampling and played a major part in deciding how the 1940 census was taken. While at the Census Bureau he applied statistical process control to the process of keypunching in order to improve the accuracy of the census questionnaire data. This increased productivity, decreased costs, and resulted in faster census results. He stayed with the Census Bureau until 1946 when he began his consulting practice and became professor of statistics at New York University. During his life time Deming contributed to almost 200 publications.

\section{AMBASSADOR FOR QUALITY IMPROVEMENT}

Beginning in early 1943 and lasting for about 2 years, Deming helped start a series of 8 week courses for industries involved in the war production efforts. These courses taught statistical process control (for understanding variation) and Plan, Do, Study, Act (PDSA) cycles (for generating new organizational knowledge). This resulted in reduced waste and improved quality of wartime production.

After the war, in 1947, to guide their rebuilding efforts, Deming advised General MacArthur's Supreme Command of Allied Powers on sampling techniques for their 1951 census in Japan. During this time he met several Japanese statisticians and was made the first Honorary Member of the Japanese Statistical Society. In 1950 he was invited back to Japan by the Union of Japanese Scientists and Engineers (JUSE) to teach statistical methods for quality improvement. Over a period of 4 years, with Deming's advice, the reputation of Japanese products changed from being equated with low quality to becoming the world leader in manufacturing excellence. In 1950 JUSE established the annual Deming Prizes consisting of a cash award, and a Deming Medal with an image of Deming and the inscription "The right quality \& uniformity are foundations of commerce, prosperity, \& peace." In 1987 the USA initiated the Malcolm Baldrige National Quality Award which is an award equivalent to the Deming Prizes. In 1955 Deming received the Shewhart Medal from what is now the American Society for Quality. In May 1960 the Emperor of Japan awarded Deming the most esteemed honor that Japan can give a foreigner-the Second Order of the Sacred Treasure.

After World War II, in relation to the rest of the world, the USA was like an unstoppable train economically, despite good or bad management. But after a few decades the 
productivity appeared to slow down relative to other countries. Deming saw this complacency and was saddened by the stagnation and lack of insight by American management. The 1970s were especially depressing. However, change was forced, as one after another major American company lost market share to the Japanese and faced the threat of bankruptcy. Then, in June 1980, NBC aired a television documentary titled "If Japan Can, Why Can't We?" and Deming was interviewed. This was the turning point for his consulting career in the USA. Shortly thereafter he embarked on his series of famous 4 day seminars which continued until his death in 1993. These seminars are still being conducted in his name. ${ }^{2}$ In 1987-27 years after his recognition in JapanPresident Reagan awarded Deming the National Medal of Technology for his work.

Deming's philosophy of quality and the essentials to quality improvement are summarized in his "system of profound knowledge" which is composed of four key elements, and his "fourteen points of management". ${ }^{34}$

The four key elements ${ }^{5}$ of his "system of profound knowledge" are:

- appreciation for a system;

- understanding variation;

- a theory of knowledge; and

- understanding psychology and human behaviour.

This means simultaneously seeing organizations as a set of interrelated processes with a common aim, understanding that processes have common cause and special cause variation, understanding how new knowledge is generated within an organization, and understanding how people are motivated and work in groups or teams in the organization.

His "fourteen points of management" ${ }^{\prime 34}$ are:*

- Point 1: Create constancy of purpose towards improvement of product and service, with the aim to become competitive and to stay in business, and to provide jobs.

- Point 2: Adopt the new philosophy. We are in a new economic age. Western management must awaken to the challenge, must learn their responsibilities, and take on leadership for change.

- Point 3: Cease reliance on mass inspection to achieve quality. Eliminate the need for inspection on a mass basis by building quality into the product in the first place.

- Point 4: End the practice of awarding business on the basis of price tag. Instead, minimize total cost. Move toward a single supplier for any one item, on a long term relationship of loyalty and trust.

- Point 5: Improve constantly and forever the system of production and service, to improve quality and productivity, and thus constantly decrease costs.

- Point 6: Institute training on the job.

- Point 7: Institute leadership. The aim of supervision should be to help people and machines and gadgets to do a better job. Supervision of management is in need of overhaul, as well as supervision of production workers.

- Point 8: Drive out fear, so that everyone may work effectively for the company.

- Point 9: Break down barriers between departments. People in research, design, sales, and production must work as a team, to foresee problems of production and in use that may be encountered with the product or service.

\footnotetext{
* Deming WE. Out of the crisis. ๑ MIT Press, 1986.
}

- Point 10: Eliminate slogans, exhortations, and targets for the work force asking for zero defects and new levels of productivity. Such exhortations only create adversarial relationships, since the bulk of the causes of low quality and low productivity belong to the system and thus lie beyond the power of the work force.

- Point 11: Eliminate work standards (quotas) on the factory floor. Substitute leadership. Eliminate management by objectives. Eliminate management by the numbers, numerical goals. Substitute leadership.

- Point 12: Remove barriers that rob the hourly workers of their right to pride of workmanship. The responsibility of supervisors must be changed from mere numbers to quality. Remove barriers that rob people in management and in engineering of their right to pride of workmanship.

- Point 13: Institute a vigorous program of education and self-improvement.

- Point 14: Put everybody in the company to work to accomplish the transformation. The transformation is everybody's job.

Leadership, organizational learning, cooperation, and systems thinking are critical to Deming's message. In areas outside health care, several success stories of organizations using Deming's methods have been published. ${ }^{6}$

\section{BEING A PATIENT}

Deming believed that $80-85 \%$ of quality (or lack thereof) was due to management. The chairman of a large Department of Pathology recently stated: "Everyone in my department is concerned about quality" - as if there were no opportunities for improvement in health care because everyone was already making their best effort. As Deming stated: "We are being ruined by best efforts" and "Best efforts will not substitute for knowledge". Deming stated: "There is an excuse for ignorance, but there is no way to avoid the consequences". For an example of this in the 1800s, see the story of Ignaz Semmelweis. ${ }^{7}$

Deming was once injured and had to spend several days in hospital. ${ }^{8}$ During this time he required a blood transfusion and intensive nursing care. He commented that the "nurses were working as hard as they could". They were well educated, but discouraged and defeated by the broken system they had to work in. Why were registered nurses making beds? The patient's shower was badly designed. Good food was served on cheap plates. Delays and delays. Treatments given varied from treatment prescribed. He recognized that the healthcare system had flaws but did not blame the people working in it. The design of this system to reduce unwanted variation in care could only be improved by a leadership that was obviously lacking.

\section{MUSICIAN AND COMPOSER}

As a young child Deming used to scribble on a piece of paper while stating that he was "writing music". His mother would then take the paper, place it on the piano, and play a tune. She would then declare that he had written great music. ${ }^{1}$

Deming went on to learn to play the drums, piano, organ, piccolo, and flute. He also composed over a dozen pieces of music, most of which are religious. He wrote a different version of music for the words to the national anthem of the USA "The Star Spangled Banner". He said that he rewrote the national anthem to make it easier for the general public to sing. He redesigned the music to improve harmony and sound, and increase singer satisfaction and cooperation. Like Avedis Donabedian, Deming also wrote poetry. As far as we 
know, Deming's music has never been recorded. Some of his compositions are to be found on the QSHC website (http:// www.qshc.com/supplemental).

\section{MAKING CHANGE HAPPEN}

Deming taught that meeting customer (and patient) needs without variation takes leadership, systems thinking, constancy of purpose, and joy in daily work life. Unvaryingly good products and service would lead to employment, prosperity and peace. Deming was ultimately effective because he followed his own advice. When few people in the USA were ready to listen to him, he went to a country that was ready to listen and change-Japan. American managers listened decades later when they no longer had a choice. Unwanted advice, like a product with defects, has few customers. When corporations were ready to listen, Deming insisted on working with the senior leaders who were the ones who could correct the systematic problems in their organization. As a patient he saw that the nurses and doctors could not work any harder, but the broken systems they were forced to work in defeated their best efforts and robbed them of joy in work. He is a hero of quality because of his relentless pursuit and endorsement of increased performance and joy in working, his criticism of unemployment or underemployment, and his advocacy of waste reduction. He was one of the first to teach that a system gets the results that it gets due to its design, and that workers in the system are not to blame. Leaders must have a vision and managers must implement the steps necessary for redesigning the system to improve quality, job satisfaction, and reduce waste. Deming stated: "Management's job is to optimize the whole system".

How do we create healthcare services where the pressures on managers to improve the systems of care are continuous and intense? One way this might occur is through extensive public reporting of comparative healthcare performance data.

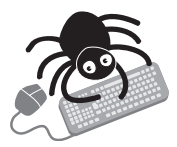

The sheet music of some of Deming's compositions are available online at http://www.qshc.com/ supplemental

\section{Authors' affiliations}

M Best, Healthcare Consultant, Eastview, KY, USA

D Neuhauser, Department of Epidemiology and Biostatistics, Case School of Medicine, Case Western Reserve University, Cleveland, $\mathrm{OH}$, USA

Correspondence to: Dr M Best, Healthcare Consultant, Eastview, KY 42732, USA; markbest20@hotmail.com

\section{REFERENCES}

1 Austenfeld RB. W. Edwards Deming: the story of a truly remarkable person, Papers of the Research Society of Commerce and Economics, Hiroshima Shudo University, Vol XXXXII, No 1. 2001:49-102.

2 W Edwards Deming Institute. http://www.deming.org laccessed 11 April 2005).

3 Walton M. The Deming management method. New York: Perigee Books, 1986.

4 Deming WE. Out of the crisis. Cambridge, MA: MIT Center for Advanced Engineering Study, 1986.

5 Deming WE. The new economics: for industry, government, education, 2nd ed. Cambridge, MA: MIT Center for Advanced Educational Services, 1994.

6 Walton M. Deming management at work: six successful companies that use the quality principles of the world-famous W Edwards Deming. New York: Perigee Books, 1990.

7 Best M, Neuhauser D. Ignaz Semmelweis and the birth of infection control. Qual Saf Health Care 2004; 13:233-4.

8 Deming WE. Some notes on management in a hospital. J Soc Health Systems, Vol 2 No 1, Spring 1990. Reprinted in, Neuhauser D, McEachern E, Headrick L, eds. Clinical CQI: a book of readings Oakbrook Terrace, IL, Joint Commission on Accreditation of Healthcare Organizations Press, 1995:183-6.

\section{Correction}

The quality improvement report entitled "Improving medication management for patients: the effect of a pharmacist on post-admission ward rounds" (M Fertleman, N Barnett, and T Patel. Qual Saf Health Care 2005; 14:207-211) was published in print with an omission from table 2. The corrected table can be viewed online at: http://qhc.bmijournals.com/cgi/content/ full/14/3/207/DC2.

doi: 10.1136/qshc.2004.11759corr1 